\title{
Pros and Cons of Monoclonal Antibodies Fixed Dosing Administration in Cancer Patients
}

\author{
Alfredo Tartarone*, Rosa Lerose and Michele Aieta \\ Department of Onco-Hematology, IRCCS-CROB Referral Cancer Center of Basilicata, Italy
}

Received: April 15, 2018; Published: April 30, 2018

*Corresponding author: Alfredo Tartarone, Department of Onco-Hematology, Unit of Medical Oncology, IRCCS-CROB Referral Cancer Center of Basilicata, Rionero in Vulture (Pz), Italy

\begin{abstract}
Monoclonal antibodies (mAbs) in oncology are usually administered in body-size-based or fixed dosing schedules. However, the minor effects of body size on distribution and elimination of $\mathrm{mAbs}$, as well as a series of practical advantages could support their fixed dosing use.

Abbreviations: FDA: US Food and Drug Administration; EMA: European Medicines Agency; NSCLC: Non Small Cell Lung Cancer; RCC: Renal Cell Carcinoma; BC: Breast Cancer; UC: Urothelial Carcinoma; CHL: Classical Hodgkin's Lymphoma; HNSCC: Head and Neck Squamous Cell Carcinoma; HCC: Hepatocellular Carcinoma; GC: Gastric Cancer; CLL: Cronic Lymphocytic Leukaemia; NHL: Non-Hodgkin's Lymphoma; FL: Follicular Lymphoma; DLBCL: Diffuse Large B-Cell Lymphoma; ; MSI-H: High Microsatellite Instability; IV: Intravenous; SC: SubCutaneous Q2W: Every Two Weeks; Q4W: Every Four Weeks
\end{abstract}

Monoclonal antibodies (mAbs) in oncology are more frequently administered in body-size-based dosing schedules as cytotoxic anticancer drugs. Simulation studies that compared the performance of body-size-based and fixed dosing of a series of mAbs in terms of pharmacokinetic and/or pharmacodynamic variability demonstrated that the preferable option could be the fixed dosing for some of them, while body-size-based dosing for some others [1,2]. However, since mAbs distribute only in extracellular fluids and blood plasma and considering that the change in volume of distribution as well as the change in blood volume is less than the change in body weight, a body-size-based dosing could result in higher plasma levels in obese patients and lower levels in underweight patients [3]. In addition the mAbs fixed dosing use showed a series of practical advantages such as a decrease of amount of drug wasting or a reduction of errors during drug preparation (Table 1).

Table 1: Pros and Cons of mAbs fixed dosing administration.

\begin{tabular}{|c|c|}
\hline Pros & Cons \\
\hline Reduction of preparation time & Administration of a higher dose than the correspondent personalized dose \\
\hline Decrease chance of dosing errors & Increase of drug cost (see above) \\
\hline $\begin{array}{c}\text { Reduced amount of drug wasting when pooling of preparation is not } \\
\text { possible }\end{array}$ & \\
\hline $\begin{array}{c}\text { Use of the preparation for other patients when treatment is cancelled at } \\
\text { the last minute }\end{array}$ & \\
\hline Reduction of inter-subject variability in drug exposure & \\
\hline *Decrease of infusion time and active healtcare professional time & \\
\hline Reduction in costs (see above) & \\
\hline
\end{tabular}

Note: *For subcutaneous formulations. 
Table 2: Flat dose of monoclonal antibodies and route of administration.

\begin{tabular}{|c|c|c|c|c|c|}
\hline \multirow[t]{2}{*}{ Name } & \multicolumn{2}{|c|}{ Approved Flat Dosing } & \multicolumn{2}{|c|}{ Oncological Indications } & \multirow[t]{2}{*}{$\begin{array}{c}\text { Route of } \\
\text { Administration }\end{array}$} \\
\hline & FDA & EMA & FDA & EMA & \\
\hline Nivolumab & $\begin{array}{c}240(\mathrm{Q} 2 \mathrm{~W}) \text { or } 480 \mathrm{mg} \\
(\mathrm{Q} 4 \mathrm{~W})\end{array}$ & & $\begin{array}{c}\text { Melanoma, NSCLC, } \\
\text { RCC, UC, cHL, HNSCC, } \\
\text { HCC }\end{array}$ & & IV \\
\hline Pembrolizumab & $200 \mathrm{mg}$ & $200 \mathrm{mg}$ & $\begin{array}{l}\text { melanoma, NSCLC, UC, } \\
\text { cHL, HNSCC, MSI-H, GC }\end{array}$ & NSCLC, cHL, UC & IV \\
\hline Pertuzumab & $\begin{array}{l}840 \text { (loading } \\
\text { dose)/420mg }\end{array}$ & $\begin{array}{l}840 \text { (loading } \\
\text { dose)/420mg }\end{array}$ & HER2 + BC & HER2+ BC & IV \\
\hline Obinutuzumab & $1000 \mathrm{mg}$ & $1000 \mathrm{mg}$ & CLL, FL & CLL, FL & IV \\
\hline Ofatumumab & $\begin{array}{l}300 \mathrm{mg}(\text { day } 1) / \\
1000 \mathrm{mg}\end{array}$ & $\begin{array}{c}300 \mathrm{mg}(\text { day } 1) / \\
2000 \mathrm{mg}\end{array}$ & CLL & CLL & IV \\
\hline Rituximab & $1400 \mathrm{mg}$ or $1600 \mathrm{mg}$ & $1400 \mathrm{mg}$ & FL, DLBCL, CLL & NHL, FL & SC \\
\hline Trastuzumab & $600 \mathrm{mg}$ & $600 \mathrm{mg}$ & HER2 + BC & HER2+ BC & SC \\
\hline
\end{tabular}

For these reasons several mAbs are actually available on the market for fixed dosing administration by intravenous (IV) or subcutaneous (SC) route (Table 2) [4]. Regarding the impact of the mAbs dosing on the costs there are divergent opinions. For example on one hand, fixed dose can reduce costs especially when pooling in preparation is not possible, on the other hand, as recently reported by Goldstein et al. for pembrolizumab, the prescribed flat dosing could be significantly higher than the correspondent personalized dose with subsequent increase in drug costs [5,6]. In conclusion, both mAbs dosing approaches can be considered in clinical practice; however, in our opinion, given also many practical advantages fixed dosing, if available, should be the preferred choice.

\section{References}

1. Wang DD, Zhang S, Zhao H, Men AY, Parivar K (2009) Fixed dosing versus body size-based dosing of monoclonal antibodies in adult clinical trials. J ClinPharmacol 49(9): 1012-1024.
2. Zhang S, Shi R, Li C, Parivar K, Wang DD (2012) Fixed dosing versus body size-based dosing of therapeutic peptides and proteins in adults. J ClinPharmacol 52(1): 18-28.

3. Hendrikx JJMA, Haanen JBAG, Voest EE, Schellens JHM, Huitema ADR, et al. (2017) Fixed dosing of monoclonal antibodies in oncology. Oncologist 22(10): 1212-1221.

4. PivotX, Gligorov J, Muller V, Barrett Lee P, Verma S, et al. (2013) Preference for subcutaneous or intravenous administration of trastuzumab in patients with HER2-positive early breast cancer (PrefHer): an openlabel randomized study. Lancet Oncol 14(10): 962-970.

5. Bach PB, Saltz LB (2017) Raising the dose and raising the cost: the case of pembrolizumab in lung cancer. J Natl Cancer Inst 109(11).

6. Goldstein DA, Gordon N, Davidescu M, Leshno M, Steuer Ce, et al. (2017) A pharmacoeconomic analysis of personalized dosing vs fixed dosing of pembrolizumab in firstline PD-L1 positive nonsmall cell lung cancer. J Nat Cancer Inst 109(11).
This work is licensed under Creative Commons Attribution 4.0 License

Submission Link: https://biomedres.us/submit-manuscript.php

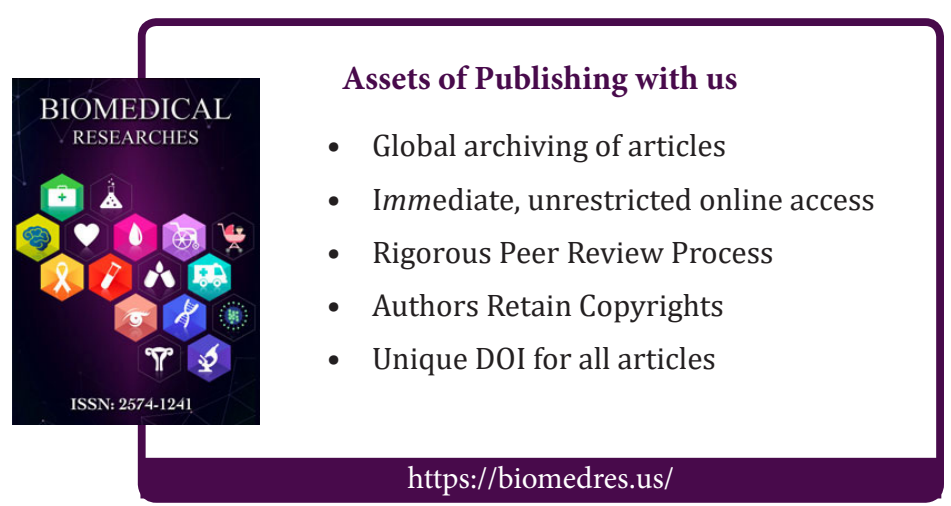

